\title{
High Speed Kernel Data Collection method for Analysis of Memory Workload
}

\author{
Jun Young Yoon ${ }^{\dagger} \cdot$ Seung Wan Jung ${ }^{++} \cdot$ Jong Woo Park ${ }^{\dagger} \cdot$ Jung-Joon $\mathrm{Kim}^{+++} \cdot$ Dae-Wha Seo $^{++++}$
}

\begin{abstract}
This paper proposes high speed kernel data collection method for analysis of memory workload, using technique of direct access to process's memory management structure. The conventional analysis tools have a slower data collection speed and they are lack of scalability due to collection only formalized memory information. The proposed method collects kernel data much faster than the conventional methods using technique of direct collect to process's memory information, page table, page structure in the memory management structure, and it can collect data which user wanted. We collect memory management data of the running process, and analyze its memory workload.
\end{abstract}

Keywords : Memory Workload, Process Memory, Linux Memory Forensic

\section{메모리 워크로드 분석을 위한 고속 커널 데이터 수집 기법 윤 준 영 $\cdot$ 정 승 완 ${ }^{++} \cdot$ 박 종 우 $\cdot$ 김 정 준 ${ }^{+++} \cdot$ 서 대 화 ${ }^{++++}$}

\begin{abstract}
요 약
본 논문은 정밀한 메모리 워크로드 분석을 위해 리눅스 기반의 커널 수준에서 프로세스의 메모리 관리 구조체에 직접 접근하는 방법을 이 용하여 고속으로 커널 데이터를 수집하는 기법을 제안한다. 기존의 분석기들은 데이터 수집 속도가 느리고 제공되는 데이터의 제한으로 인하여 확장성이 부족하다. 제안 기법은 메모리 관리 구조체 내의 프로세스 메모리정보, 페이지 테이블, 페이지 구조체를 직접 수집하는 방법을 이용하 여 기존의 기법 보다 빠르게 커널 데이터를 수집하며, 사용자가 원하는 데이터를 선택하여 수집할 수 있다. 제안 기법을 통해 실제 실행 중인 프로세스의 메모리 관리 데이터를 수집하고 메모리 워크로드에 대한 분석을 수행하였다.
\end{abstract}

키워드 : 메모리 워크로드, 프로세스 메모리, 리눅스 메모리 포렌식

\section{1. 서 론}

컴퓨터 시스템의 메모리 분석은 새로운 운영체제를 설계 하거나 소프트웨어의 메모리 관련 문제를 분석하여 시스템 의 성능 향상, 시스템 공격에 대한 원인 분석 등과 같은 목 적으로 수행된다. 최근 들어 컴퓨터 하드웨어의 성능이 전 반적으로 향상되어 소프트웨어에 대한 사용자의 요구 수준 이 높아짐에 따라 소프트웨어들의 성능이 증가하고, 구현

※ 본 연구는 지식경제부 및 정보통신산업진흥원의 IT 융합 고급인력과정 지원사업(NIPA-2013-H0401-13-1005)의 연구결과로 수행되었으며, 2012 학년도 경북대학교 학술연구비 지원을 받았음.

† 준 회 원: 경북대학교 전자공학부 석사과정

†† 준 회 원: 경북대학교 전자전기컴퓨터학부 박사과정

†申† 정 회 원: 경북대학교 전자공학부 교수

+十+† 종신회원 : 경북대학교 전자공학부 교수

논문접수: 2013년 9월 23일

수 정 일 : 1차 2013년 10월 23일, 2차 2013년 11월 4일

심사완료 : 2013년 11월 4일

* Corresponding Author:Dae-Wha Seo(dwseo@ee.knu.ac.kr)
측면의 복잡도가 높아졌다. 하지만 시스템 소프트웨어 또는 임베디드 소프트웨어들은 메모리 자원이 한정되어 있기 때 문에 여전히 프로그래머에게 메모리 사용에 대한 부담을 가 중시키면서 메모리와 관련된 다양한 문제점을 발생시킨다. 따라서 메모리와 관련된 다양한 문제를 해결하기 위하여 프 로세스에 대한 메모리 분석은 필수적으로 요구된다.

오픈 소스의 장점을 가지는 리눅스 커널은 운영체제 관련 연구에서 널리 사용되고 있으나 리눅스 커널 기반의 메모리 분석에 관한 연구는 활발히 이루어지지 않고 있다.

기존의 다양한 리눅스 커널 기반의 메모리 분석기는 메모 리 정보를 수집하고 분석하기 위해 커널에서 제공하는 Proc 파일시스템과 메모리 코어 덤프(Memory Core Dump)를 이 용한다[1, 2].

Proc 파일시스템은 유닉스 계열의 운영체제에서 사용되 고 있으며, 사용자 수준(User Level)에서 접근하여 이용할 수 있는 특수한 가상 파일시스템이다. Proc API(Application 
Programming Interface)를 이용하여 사용자 또는 커널 수준 (Kernel-Level)에서 프로그램을 작성하거나, 루트 파일시스 템 내부의 /proc 디렉토리로 접근하여 사용할 수 있다[3]. Proc 파일시스템은 커널의 방대한 정보를 제공하지만, 정형 화된 데이터를 추출하여 분석에 활용할 수 있는 정보로 편 집하는 새로운 프로그램의 작성이 필요하다.

메모리 코어 덤프는 실제 물리 메모리의 물리 주소를 가 상 주소로 매핑하여 접근하고, 지정하는 크기만큼의 물리 메모리 공간 내에 데이터를 수집하는 방법이다[4]. 저장된 데이터는 실제 물리 메모리의 지정 영역에 대한 정보이기 때문에 물리 메모리의 데이터를 직접 확인할 수 있는 장점 이 있다. 그러나 현재 리눅스는 시스템 보호 문제로 메모리 에 직접 접근하기 위한 방법이 없기 때문에 덤프를 위한 장 치 파일 및 도구가 필요하다. 또한, 수집되는 데이터는 바이 너리 형태이므로 분석이 매우 힘들며, 실제 물리 메모리에 접근하여 데이터를 수집하기 때문에 데이터의 양이 상당히 많고, 속도가 느려지므로 데이터를 빠르게 분석하기에는 큰 어려움이 있다. 그리고 메모리 코어 덤프는 연속적인 물리 메모리의 내용을 가져오는데 특화된 분석기로 해당 프로세 스의 메모리 정보만 덤프하기 위해서는 매우 많은 부가적인 작업이 필요하다.

특정 프로세스가 동작중일 때, 프로세스의 메모리와 메모 리 관리 정보는 매우 빠른 속도로 변화 및 갱신된다. 빠르 게 변경되는 메모리 관리 정보를 이용하여 메모리 워크로드 를 분석하기 위해서는 프로세스의 메모리에서 변화 및 갱신 되는 메모리 관리 정보와 메모리 할당/해제에 대한 정보를 빠르게 파악할 수 있는 수집 기법이 필요하다. 그리고 프로 세스의 특정 동작 시나리오에서 메모리 워크로드를 추적하 기 위해 프로세스 특정 영역(힙, 스택 등)에 대한 메모리 정 보를 선택적으로 수집할 수 있는 방법이 필요하다. 그러므 로 본 논문에서는 리눅스 커널 기반의 프로세스 메모리 워 크로드를 분석하기 위한 고속 커널 데이터 수집 기법을 제 안한다. 기존의 메모리 코어 덤프는 메모리 해당 영역 전체 를 복사하는 방법을 사용한다. 하지만 제안하는 기법은 커 널 수준의 모듈을 통하여 분석 대상 프로세스의 관리 정보 및 사용 중인 물리 페이지 구조체를 직접 수집하는 방법을 사용하여 필요한 정보만을 가져온다. 프로세스의 관리 정보 및 물리 페이지에 대한 정보는 항상 물리 메모리 공간상에 유지되고 있기 때문에 신뢰성 있는 데이터를 빠르게 획득할 수 있는 장점을 가진다. 제안하는 방법을 이용하면 실제 물 리 메모리 전체를 직접 접근하지 않고 프로세스가 사용 중 인 물리 페이지 구조체에 접근하여 데이터를 고속으로 수집 할 수 있다. 그리고 물리 메모리에 대한 대부분의 정보를 얻을 수 있기 때문에 필요한 데이터를 선택적으로 수집하여 특정 영역에 대한 사용량을 알 수 있다.

본 논문의 구성은 2 장에서 기존에 개발된 메모리 분석기 들을 소개하고, 3 장에서 제안하는 커널 데이터 수집 기법 대해 기술한다. 4 장에서는 분석기의 구현을 통한 메모리 워 크로드의 분석 결과를 기술하며, 마지막으로 5 장에서 결론 을 서술한다.

\section{2. 관련 연구}

본 장에서는 리눅스 기반 메모리 분석 도구의 특징과 문 제점을 살펴본다.

유닉스와 리눅스 계열의 운영체제에서는 기본적인 시스템 정보를 사용자가 더욱 쉽게 접근하여 사용할 수 있도록 Proc 파일시스템을 제공한다. Procps[5] 유틸리티는 Proc 파 일시스템을 이용하여 시스템 정보를 제공하는 대표적인 시 스템 유틸리티 집합으로, 시스템의 전체 메모리와 프로세스 의 상태, 스케줄링 변경, 사용 메모리, 가상 메모리 정보 등 을 제공하고 있으며, 메모리의 정보를 확인하거나 시스템을 감시하는 등의 단순한 작업에 주로 사용된다.

Foriana[6], Second Look[7], Draugr[8]는 메모리 코어 덤 프 방법을 사용하는 분석기로 메모리 코어 덤프 유틸리티를 따로 제공하며, 덤프 도구를 통해 추출한 덤프 이미지를 분 석하여 프로세스, 모듈, 파일 목록 등의 정보를 제공한다. Second Look은 상용화 분석기로 메모리 상에서 시스템 공 격이 의심되는 라이브러리 및 패턴을 탐지하는 기능도 지원 하고 있다.

Red Hat Crash Utility[9]는 시스템 크래시 분석 유틸리 티로 시스템 또는 시스템 내의 프로세스에 문제가 생길 경 우 생성되는 코어 덤프 이미지를 분석한다. 최초의 버전에 서는 디버깅을 위해 설계되었지만, 현재 메모리 분석용으로 도 사용되고 있다.

Volatilitux[10], Volatile Framework[11]는 Foriana와 Second Look에서 사용되는 코어 덤프의 느린 속도를 개선 하고 많은 기능을 제공하는 분석기이며, Proc 파일시스템과 메모리 코어 덤프방법 두 가지 모두를 사용하여 메모리 분 석을 위한 데이터를 수집한다. Volatilitux는 인터프리터 언 어인 파이썬으로 작성된 메모리 분석기이며, 다양한 운영체 제 환경을 지원한다.

위의 세 가지 방법 외에도 커널 페이지만 덤프하는 기능 을 가지는 LiME[12]은 본 논문에서 제안하는 커널 데이터 수집 방법과 흡사한 기법을 사용하고 있으며, 최근에는 임 베디드 리눅스에서도 사용할 수 있도록 지원하고 있다. 하 지만 커널 영역 내의 데이터만을 수집할 수 있다는 단점을 가진다.

Idetect[13]는 프로세스에 대한 분석을 위한 분석기로 커 널 수준에서 프로세스의 관리 정보를 수집하여 사용자에게 제공한다. 하지만 제한적인 데이터로 인해 정밀한 분석을 위해서는 메모리 코어 덤프 도구가 필요하다.

기존의 다양한 분석기 및 수집기들은 데이터를 수집하기 위한 별도의 프로그램 작성이 필요하거나, 데이터의 수집 속도가 느리며, 커널 영역 내의 메모리 정보만 수집 할 수 있는 문제점을 가지고 있다. 그리고 방대한 데이터를 직접 수집하여 분석해야 되기 때문에 프로세스 별 메모리 워크로 드를 분석하는데 있어 큰 어려움이 따른다. 따라서 프로세 스 별 메모리 워크로드를 분석하기 위하여 고속으로 커널 데이터를 수집하는 수집 도구의 개발이 필요하다. 


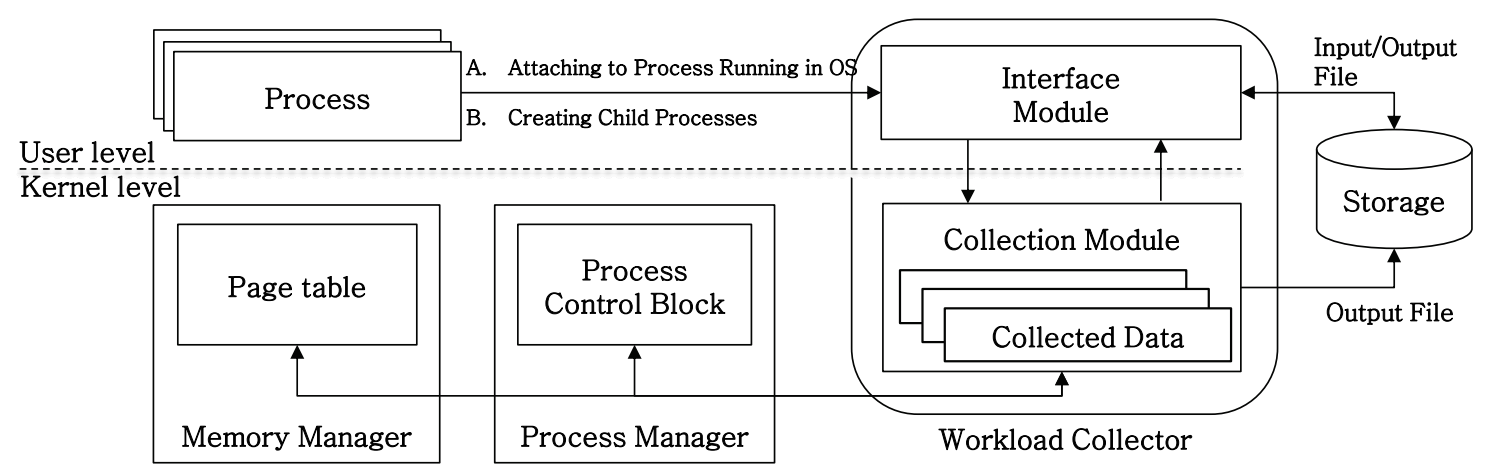

Fig. 1. Architecture of Memory Workload Collector

\section{3. 프로세스 메모리 사용 관련 커널 데이터 수집 기법}

본 장에서는 사용자가 지정하는 프로세스의 메모리 워크 로드를 분석하기 위하여 컴퓨터 시스템에서 수행되고 있는 타겟 프로세스의 메모리 사용 관련 커널 데이터를 고속으로 수집하는 기법에 대해서 기술한다.

커널 내에 있는 각 프로세스는 자신만의 $\mathrm{PCB}$ (Process Control Block)를 가지고 있으며, $\mathrm{PCB}$ 는 프로세스가 사용하 고 있는 메모리에 대한 정보를 가진 메모리 관리 구조체의 위치 정보를 가지고 있다. 위치정보를 통해 프로세스의 메 모리 관리 구조체에 빠른 속도로 접근하면 해당 프로세스의 메모리 상태 정보와 메모리 사용량, 각 영역 별 가상 주소 범위, 가상 영역의 크기, 가상 주소와 물리 주소의 매핑 정 보, 페이지 수정 빈도, 페이지 및 영역별 참조 횟수 등의 프 로세스에 대한 전체적인 메모리 정보를 획득할 수 있다.

제안 기법을 설명하기 위하여 3.1절에서는 고속으로 메모 리 워크로드를 수집하는 전체적인 구조와 각 모듈의 기능에 대하여 간략하게 기술하고, 3.2절에서는 타겟 프로세스의 $\mathrm{PCB}$ 와 메모리 관리 구조체에 접근하여 메모리 관련 정보를 고속으로 수집하는 방법을 기술한다.

3.1 메모리 워크로드 분석을 위한 메모리 워크로드 수집기 의 전체 구조

본 논문에서 제안하는 메모리 워크로드 분석을 위한 커널 데이터 수집 기법은 커널의 방대한 메모리 관련 데이터를 선택적으로 수집하여 분석을 위한 정보를 추출하는 작업을 수행한다.

Fig. 1은 메모리 워크로드 수집기에 대한 전체구조를 나 타낸다. 제안하는 수집기는 사용자와 커널 수준의 상호 연 결을 위한 인터페이스 모듈(Interface Module)과 커널 데이 터를 수집하기 위한 콜렉션 모듈(Collection Module)로 구성 된다.

제안하는 수집기는 이미 실행 중인 프로세스의 메모리 관 련 데이터를 수집할 수 있고, 특정 프로세스를 생성시켜서 프로세스의 메모리 관련 데이터를 수집한다. 두 가지의 수 집 방법은 메모리와 관련된 데이터 수집 과정이 동일하며,
인터페이스 모듈을 통하여 사용자의 선택에 의해 결정된다. 콜렉션 모듈에서는 타겟 프로세스의 PID(Process ID)를 이 용해서 해당 프로세스의 $\mathrm{PCB}$ 정보를 획득할 수 있으며, 메 모리 관리 구조체에 접근하여 프로세스의 메모리 관련 데이 터를 수집할 수 있다.

\section{1) 인터페이스 모듈(Interface Module)}

인터페이스 모듈은 사용자와의 인터페이스를 위한 부분으 로 사용자 수준에서 동작한다. Fig. 2 는 인터페이스 모듈의 동작 흐름을 나타낸다. 모듈은 커널 수준의 콜렉션 모듈을 로드하고, 로드된 콜렉션 모듈과 통신하기 위한 연결부인 장치 파일(Device File)을 생성한다. 생성된 장치 파일을 통 해 모듈의 $\operatorname{read}()$ 함수와 write() 함수로 접근하며, 콜렉션 모듈과 통신 수단으로 사용된다.

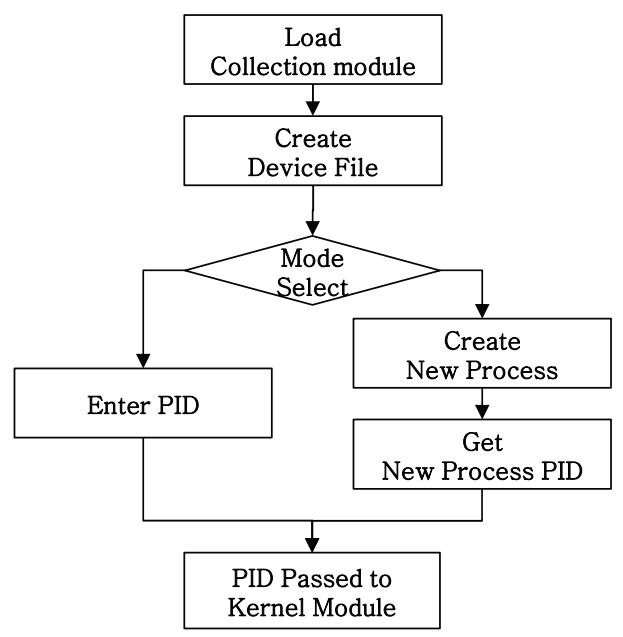

Fig. 2. Operation of Interface module

실행 중인 프로세스를 분석하기 위해서는 해당 프로세스 의 $\mathrm{PID}$ 를 직접 입력받게 되고, 프로세스의 $\mathrm{PID}$ 가 장치 파일 (연결부)을 거쳐서 콜렉션 모듈로 전달된다. 새로운 프로세 스를 생성해서 분석을 하는 경우에는, 인터페이스 모듈이 프로세스를 생성하고, 생성된 프로세스의 $\mathrm{PID}$ 를 장치 파일 (연결부)을 거쳐서 콜렉션 모듈로 전달하게 된다. 
두 가지 경우 모두 프로세스의 메모리 관련 데이터 수집 은 동일한 방식을 취하지만 사용 목적에 있어 차이를 가진 다. 실행 중인 프로세스의 메모리 정보를 수집하는 것은 먼 저 프로세스의 특정 상황에 대한 메모리 사용 패턴을 분석 하는 목적으로 주로 사용한다. 반면에 새로운 프로세스를 생성하여 메모리 정보를 수집하는 것은 해당 프로세스의 전 반적인 메모리 사용 패턴을 분석하는 목적으로 사용한다.

\section{2) 콜렉션 모듈(Collection Module)}

Fig. 3은 콜렉션 모듈의 동작을 나타낸다. 콜렉션 모듈에 서는 인테페이스 모듈에서 넘겨받은 $\mathrm{PID}$ 를 이용해서 타겟 프로세스의 $\mathrm{PCB}$ 내 메모리 관리 구조체의 위치 정보를 획 득하여 메모리 관리 구조체에 접근한다. 메모리 관리 구조 체 내에 있는 가상 메모리와 관련된 데이터들을 수집하고, 메모리 관리 구조체 내에 있는 타겟 프로세스의 페이지 테 이블 위치정보(PGD; Page Global Descriptor)를 이용해서 페이지 테이블에 접근한다. 그리고 페이지 테이블을 이용해 서 가상 주소를 물리 주소로 변환하고, 물리 메모리에 대한 정보를 수집한다. 콜렉션 모듈의 수집 과정을 통해 수집된 메모리 워크로드 정보들은 인터페이스 모듈을 통해서 사용 자에게 제공된다.

\section{2 프로세스 메모리 사용 관련 커널 데이터 수집 과정}

본 절에서는 콜렉션 모듈에서 타겟 프로세스의 메모리 관 련 데이터를 수집하는 과정에 대하여 상세하게 기술한다.

프로세스의 메모리 관련 데이터를 수집하기 위해서는 우 선적으로 해당 프로세스의 메모리 관리 구조체(mm_struct) 에 대한 접근이 필요하다. Fig. 4는 타겟 프로세스의 $\mathrm{PCB}$ 를 탐색하여 해당 $\mathrm{PCB}$ 내의 메모리 관리 구조체에 접근하는 과정을 나타내고 있다.

먼저 타겟 프로세스의 $\mathrm{PID}$ 를 이용하여 프로세스 실행 큐 (Process Run Queue)에 등록된 $\mathrm{PCB}$ 리스트를 순차적으로

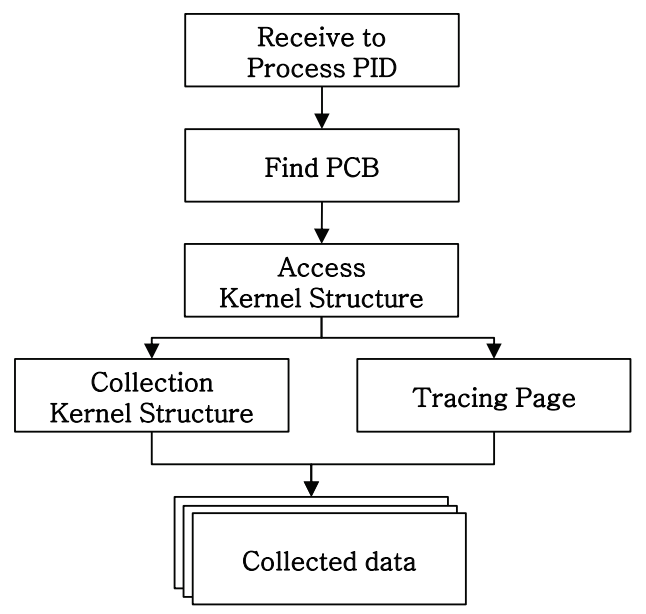

Fig. 3. Operation of Collection module

탐색한다. 타겟 프로세스의 $\mathrm{PCB}$ 를 찾으면, 타겟 프로세스의 $\mathrm{PCB}$ 주소 값을 모듈 내에 저장하여 프로세스가 종료되거나 데이터 수집을 중지하는 순간까지 유지하게 된다. 그리고 $\mathrm{PCB}$ 내의 메모리 관리 구조체에 접근 가능한 주소를 유지 하면서 메모리 관리 구조체에 접근한다.

메모리 관리 구조체는 가상 메모리에 관련된 정보 (vm_area_struct)와 페이지 테이블의 위치 정보 등을 가지 고 있으며, 일반적으로 메모리 관리 구조체 정보들의 생성, 수정, 해제 등의 관리는 커널의 메모리 관리자(Memory Manager)가 담당한다.

커널 데이터 수집기는 메모리 관리 구조체에 접근하여 타 겟 프로세스의 각 가상 메모리 영역에 대한 정보를 획득한 다. 그리고 획득한 정보에서 프로세스의 워크로드 분석에 필요한 데이터를 수집하며, 페이지 테이블에 대한 위치 정 보를 획득하여 해당 물리 페이지 구조체에 접근한다.

프로세스의 메모리 상태는 계속적으로 변화하므로, 수집 시간이 오래 걸리는 물리 메모리 덤프 방법보다는 프로세스

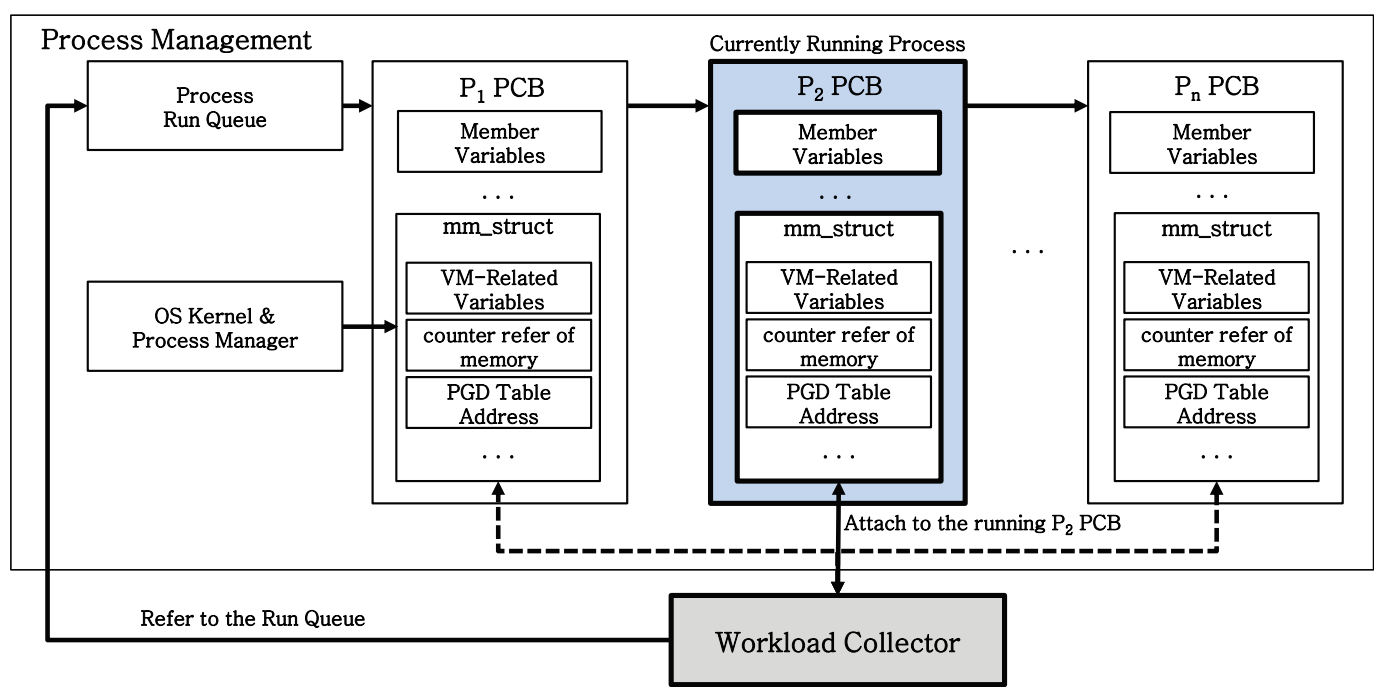

Fig. 4. The method for accessing mm_struct 
에서 사용하고 있는 물리 페이지 구조체에 직접 접근하여 필요한 데이터를 수집하는 방법을 통해 고속으로 물리 메모 리의 정보를 수집할 수 있다.

페이지 구조체는 물리 메모리의 페이지 프레임 별 상태 정보를 가지고 있으며, 커널 영역에서 연결 리스트 형태로 관리 되고 있다. 커널의 데이터 구조를 바탕으로 Fig. 5는 프로세스가 사용하고 있는 물리 페이지의 상태 정보를 수집 하는 과정을 보여준다. 타겟 프로세스에서 사용되는 가상 주소를 이용하여 해당 페이지 테이블 엔트리를 확인하면, 매핑되는 물리 주소와 페이지의 존재 여부를 확인할 수 있 다. 페이지가 메모리 내에 존재한다면 물리 주소 값과 물리 메모리의 시작 주소를 이용하여 페이지 프레임 넘버(PFN; Page frame number)를 계산할 수 있다. 그리고 페이지 리 스트에서 페이지 프레임 넘버에 해당하는 페이지 구조체를 찾아 정보를 수집한다.

해당 가상 주소에 대한 메모리 정보를 수집하는 과정을 가상 주소 영역 전체를 대상으로 수행하면 프로세스 전체의 메모리 사용 정보를 수집할 수 있다. 또한 프로세스의 종료 혹은 수집의 종료 시 까지 반복적으로 수행하면 특정 시간 동안 수행된 프로세스의 메모리 관련 데이터를 고속으로 수 집할 수 있다.

타겟 프로세스의 메모리 관련 데이터는 특정한 주기로 수 집하는 것이 가능하다. 일반적인 커널은 프로세스에 대한 상태 정보를 최신으로 유지하게 되며, 유지를 위한 커널 정 보 업데이트는 즉각적인 변경과 특정 시점에서의 변경 방법 이 있다. 즉각적인 변경은 프로세스가 사용하는 자원에 관
련된 모든 부분이 변경될 때 일어나며, 특정 시점의 변경은 문맥 교환(Context Switching)에서 일어난다. 메모리 정보 수집 주기는 앞서 말한 두 시점을 고려하여 데이터를 수집 할 수 있도록 커널 데이터 수집에 대한 샘플링 주기를 직접 조절한다.

\section{4. 구현 및 분석 결과}

\section{1 모듈 구현}

커널 데이터 수집기는 데이터를 원활하게 수집하기 위 해 사용자 수준의 모듈과 커널 수준의 모듈로 분리하여 구현하였다. 그리고 각 모듈은 $\mathrm{GNU} \mathrm{C}$ 컴파일러를 이용하 여 C 언어로 프로그래밍 하였으며, 커널 수준의 모듈은 커 널에서 물리 페이지 구조체에 접근하기 위해 커널 $\mathrm{API}$ 와 모듈 프로그래밍을 통해 구현하였다. 커널 자체를 수정하 지 않고 일반적인 응용 프로그램과 커널에 삽입가능 한 라이브러리 형태의 모듈로 구현되었기 때문에 설치 및 배 포가 용이하다.

\section{2 분석 환경}

\section{1) 구현 및 분석 환경}

메모리 워크로드 수집기에서 수집된 데이터를 이용하여 프로세스에 대한 메모리 워크로드를 분석하기 위해 제안하 는 수집기의 구현 및 분석 환경은 다음과 같다.

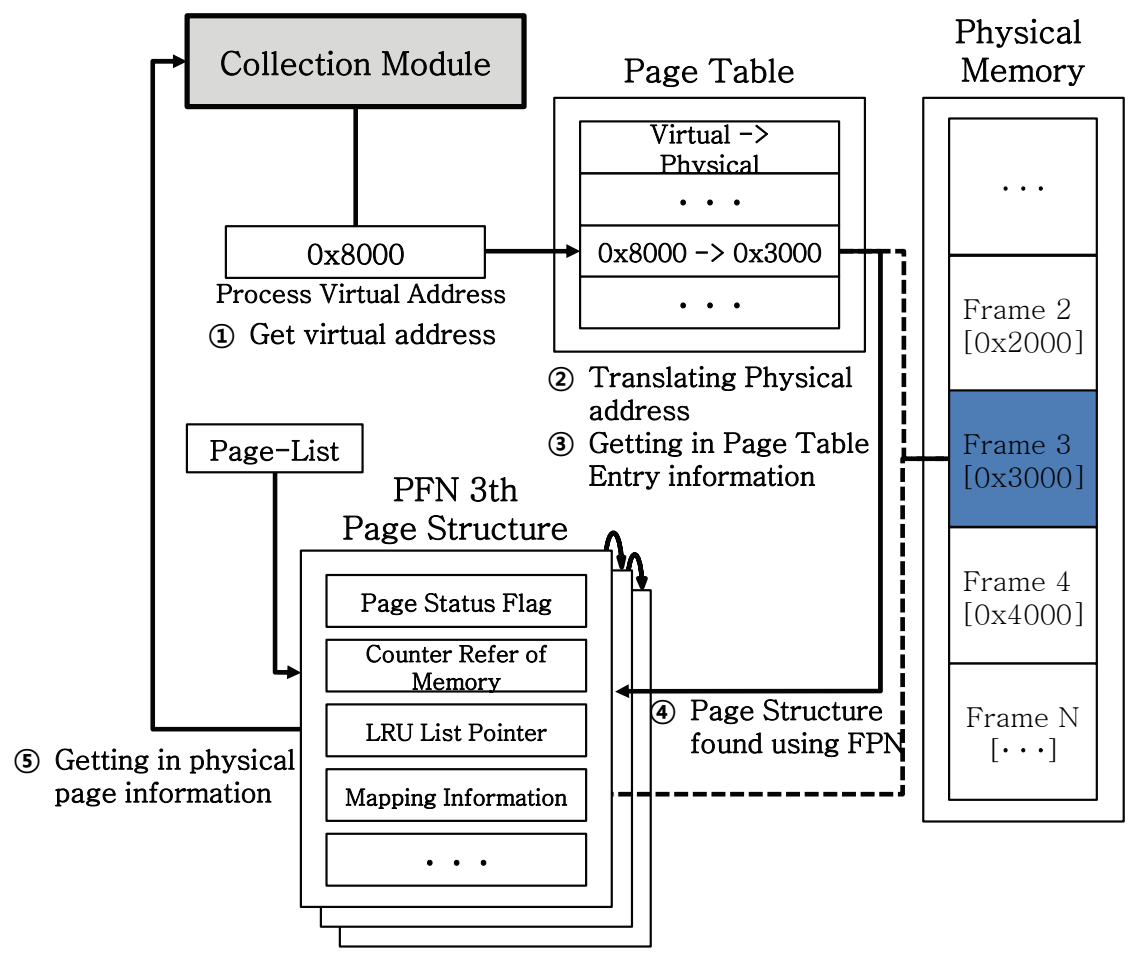

Fig. 5. Trace page and get physical page information 
- CPU : Intel Core i7-860(2.80GHz)

- Memory : DDR3 2GB(1,600MHz)

- OS : Desktop Linux Kernel Ver. 3.2.0 32bit

\section{2) 분석 타겟 프로세스의 정의}

분석 타겟이 되는 프로세스는 리눅스에서 일반적으로 자 주 사용되는 단순 텍스트 출력 프로그램인 Tail과 확장 텍 스트 편집기인 $\mathrm{Vim}$ 을 대상으로 하였다.

두 프로세스 중 Tail은 특정 파일을 열고 파일에 추가되 는 마지막 텍스트만 출력하는 프로그램으로 코드의 구조가 단순하고 반복적인 작업으로 이루어져 있다. Vim은 리눅스 에서 가장 많이 사용되는 텍스트 편집 프로그램으로 안전성 이 높고 부가적인 기능과 텍스트 편집이라는 특성으로 인해 많은 메모리를 사용할 수 있다.

\section{3 분석 결과}

메모리 워크로드 수집기를 이용하여 프로세스의 메모리 워크로드 분석을 진행하였다. 두 프로세스의 수집 결과를 통해 최소한의 추출 가능한 데이터 범위를 도출하고, 도출 된 결과를 이용하여 프로세스의 메모리 워크로드 분석을 진 행하였다.

\section{1) 수집 속도 결과}

프로세스의 메모리 워크로드 분석을 위해 메모리 워크로 드 수집기를 이용하여 프로세스의 커널 데이터를 주기적으 로 수집하였다. Fig. 6은 특정 프로세스의 커널데이터를 주 기적으로 수집한 결과를 보여준다. 수집되는 데이터에 대한 포맷은 데이터 수집 시간, 한 주기의 데이터 수집 소요시간, 메모리 관리 구조체에서 수집한 메모리 정보, 페이지 구조 체에서 수집한 페이지 정보로 구성되어 있다.

데이터 포맷의 첫 번째 부분은 수집 시간을 나타내며, $\mu \mathrm{s}$ 단위로 시간을 나타낸다. 평균 $100 \mathrm{~ms}$ 의 주기로 수집하는 것을 볼 수 있으며, 수집에 대한 주기는 $\mu \mathrm{s}$ 단위로 조절 가 능하지만, 평균적인 수집 주기의 오차는 $10 \%$ 미만이고, 시 스템의 부하로 인해 최대 $30 \%$ 까지 오차를 가질 수 있다. 허용 가능한 시스템 부하 내에서 안정적으로 수집이 가능한 최소의 수집 주기는 $10 \mathrm{~ms}$ 이며, 시스템의 성능에 따라 달 라질 수 있다.

두 번째 부분은 프로세스의 전체 페이지를 한번 수집하는 데 소요되는 시간이다. Fig. 6(A)와 (B)에서 Tail 프로세스 는 평균 $400 \mu \mathrm{s}, \mathrm{Vim}$ 프로세스는 평균 $5 \mathrm{~ms}$ 가 소요되는 것을 볼 수 있다. 두 프로세스는 동일한 조건의 실행환경에 서 수행하였으며, 두 프로세스 간 수집 소요시간은 약 12 배 정도의 차이가 나고 있다는 것을 보여주고 있다. Fig. 6의 결과를 통해 두 프로세스가 사용 중인 메모리 크기, 현재 운용중인 운영체제 서비스와 실행 중인 다른 프로세스와의 문맥 교환에 대한 오버헤드로 인해 한 주기 수집 시간이 달 라질 수 있다는 것을 알 수 있다. 그리고 한 주기 수집 소 요시간에 큰 영향을 받는 것은 수집 시간과 비슷한 차이가
나는 사용 중인 메모리 크기라는 것을 알 수 있다.

세 번째와 네 번째 부분은 메모리 관리 구조체의 종합적 인 메모리 관리 정보와 페이지 구조체의 종합적인 정보이며, 한 주기 동안 메모리 관리 구조체와 페이지 구조체의 간략 한 사용정보를 나타낸다. 현재 Tail 프로세스는 전체적으로 143 개의 페이지와 약 $5.5 \mathrm{MB}$ 의 메모리를 사용하고 현재 19 개의 변경되는 페이지가 있다는 것을 알 수 있으며, Vim 프 로세스는 2560여개의 페이지와 약 $48.7 \mathrm{MB}$ 의 메모리를 사 용하고 980 여개의 변경되는 페이지가 존재하며, 사용되는 메모리가 증가하고 있는 것을 보여주고 있다.

Fig. 6(B)에서 텍스트 파일을 열었을 때 메모리 사용량의 변화를 확인할 수 있다. Vim 프로세스를 실행하고 약 50 $\mathrm{MB}$ 의 텍스트 파일을 열었을 때의 결과로써 사용되는 메모 리의 크기가 급격히 증가하고 페이지 관련 정보들이 급격히 변화하는 것을 볼 수 있다.

본 논문에서 제안하는 메모리 워크로드 수집 기법과 기존 의 방법들을 비교하기 위해 위 실험과 동일한 환경에서 각 방법들의 속도를 비교 하였다. 먼저, Proc 파일시스템을 이 용하여 프로세스 메모리 정보를 수집하는 Pmap 유틸리티를 통해 두 프로세스의 메모리 정보 수집을 수행하였다. 그 결 과, 한 주기 수집 속도에 있어 Tail 프로세스가 평균 1.3 $\mathrm{ms}, \operatorname{Vim}$ 프로세스가 평균 $15 \mathrm{~ms}$ 가 소요되었다. 메모리 코 어 덤프 방법은 메모리 덤프 도구를 통해 프로세스 메모리 크기와 동일한 크기의 연속되는 메모리 공간을 덤프 하였 다. 두 프로세스 각각의 크기에 대한 덤프 수행 결과로 Tail 프로세스와 같은 메모리 크기의 덤프는 평균 $41 \mathrm{~ms}, \mathrm{Vim}$ 프로세스와 같은 메모리 크기의 덤프는 평균 $333 \mathrm{~ms}$ 가 소 요되었다.

실험 결과를 통해 메모리 워크로드 수집기의 수집 속도는 기존의 Proc 파일시스템을 이용하는 방법보다 약 3배 이상 빠르며, 메모리 코어 덤프보다 약 80 배 이상 빠른 것을 알 수 있다. 제안하는 수집기는 커널 데이터 수집하고 이를 원 하는 정보로 편집하는데 커널 데이터 수집 속도 $\times$ 페이지 개수 만큼의 시간이 소요되며, 프로세스 페이지 개수 $\times$ 페 이지 구조체 크기(32 byte) 만큼의 데이터를 수집한다. Proc 파일시스템을 이용하는 Pmap 유틸리티의 수집 속도가 제안 하는 수집기보다 느린 이유는 Proc 파일시스템을 이용하면 서 발생하는 오버헤드 때문이다. Proc 파일시스템에 접근하 여 필요한 데이터를 문자열 형태로 읽어 들이면서 발생하는 콜백 함수에 대한 오버헤드, 정보를 편집하기 위해 문자열 로 이루어진 데이터를 수치 데이터로 변환해야하는 부가 작 업, 그리고 제안하는 수집기와 동일한 정보를 출력하기 위 하여 흩어진 파일에서 필요한 데이터를 수집하여 편집하는 오버헤드로 인해 (커널 데이터 수집 속도 $\times$ 페이지 개수) + ((콜백 함수 오버헤드 + 데이터 변환 시간 + 데이터 편집 시간) $\times$ 가상 메모리 공간의 개수) 만큼의 시간이 소요되며, Proc 파일시스템을 이용하여 데이터를 편집하는 과정에서 수집 속도의 저하가 생긴다. 메모리 코어 덤프의 수집 속도 에 대한 차이는 수집되는 데이터의 크기 차와 수집된 데이 


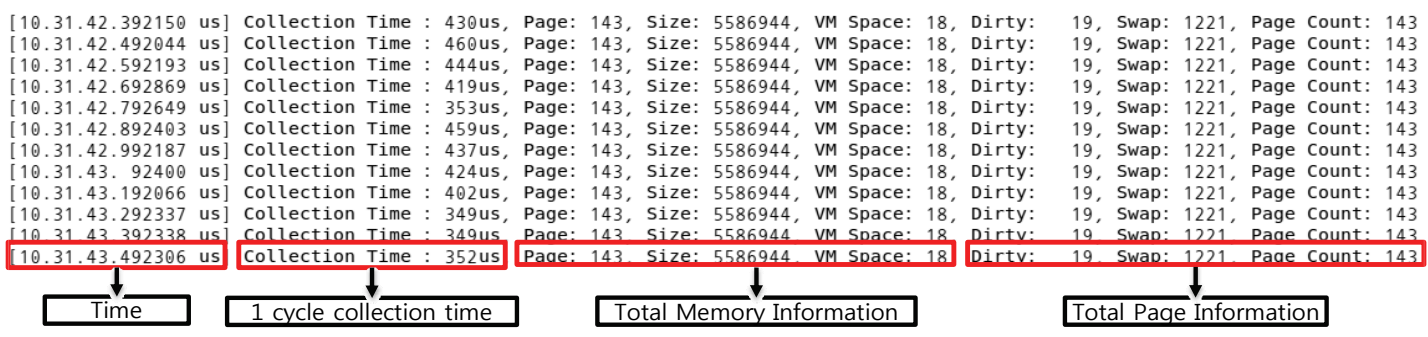

(A) Tail Process

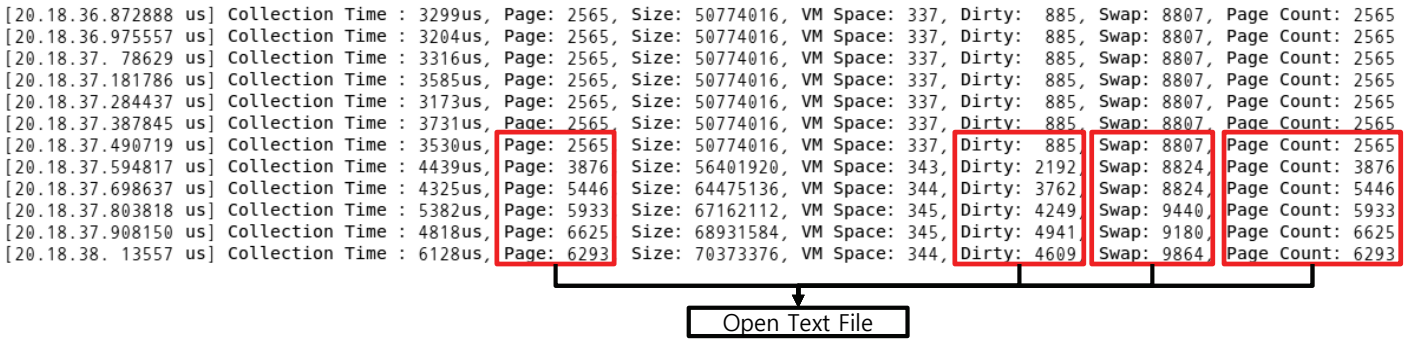

(B) Vim Process

Fig. 6. High speed data collection result of the specific process

터를 저장하는 공간이 다르기 때문이다. 메모리 코어 덤프 는 프로세스 페이지 개수 $\times$ 페이지 크기 $(4 \mathrm{~KB})$ 만큼의 데 이터를 수집하므로 수집되는 데이터의 양이 프로세스 크기 와 같아진다. 그리고 덤프 결과를 확인하기 위해서는 프로 세스 크기만큼의 저장 공간이 필요하며, 느린 대용량 보조 기억장치에 저장함으로써 전체적인 속도 저하가 생긴다. 본 실험을 통해 제안하는 메모리 워크로드 수집 기법의 수집 속도는 기존의 방법들 보다 빠르며, 수집 속도가 프로세스 의 크기에 따라 최소 $300 \mu \mathrm{s}$ 최대 $40 \mathrm{~ms}$ 를 소요하므로 고속의 수집 속도를 보장한다.

\section{2) 특정 프로세스 데이터 수집 결과}

메모리 워크로드 수집기에 수집 가능한 데이터의 범위를 알기위해 Tail 프로세스와 Vim 프로세스에 대한 커널 데이 터를 수집하고, 각 프로세스의 커널 데이터를 분석하였다. Fig. 7은 Tail과 Vim 프로세스의 각 영역에 대한 한 주기의 수집 결과이다. Fig. 7(A)는 Tail 프로세스의 한 주기 수집 결과를 나타내며, 정적 공유 라이브러리 영역과 프로세스 영역으로 나뉘는 것을 확인할 수 있다. 정적 공유 라이브러 리 영역은 리눅스 시스템 전역에서 공유되는 라이브러리들 이 위치한다. 그리고 프로세스 영역은 프로세스가 사용하는 영역으로 프로세스 메모리 구조와 동일하다. 수집 결과만으 로 프로세스에 대한 가상 메모리 영역의 주소, 크기, 변경되 는 페이지, 프로세스의 실제 물리 메모리 사용량을 알 수 있으며, Tail 프로세스가 참조하고 있는 동적 라이브러리도 확인할 수 있다.

Fig. 7(B)는 Vim 프로세스의 한 주기 수집 결과이며, 많 은 양의 데이터로 인해 정적 공유 라이브러리 제외한 실제 프로세스가 사용하는 영역만을 나타내었다. 두 프로세스의 결과에서 Text 영역의 페이지 개수를 살펴보면 Tail 프로세
스는 56 개, $\operatorname{Vim}$ 프로세스는 2148 개로 약 38 배의 차이가 나 며, Heap 영역은 Tail 프로세스가 132개, Vim 프로세스는 2012개로 Vim 프로세스가 상대적으로 많은 페이지를 할당 하고 있는 것을 볼 수 있다. 각 영역별 수집 결과를 통해 각 프로세스의 특징을 확인할 수 있다. Tail 프로세스는 코 드가 단순하고 크기가 작으며, 커널 메시지가 기록되는 파 일의 추가되는 부분을 반복적으로 출력하기 때문에 많은 메 모리가 필요하지 않는다는 것을 확인할 수 있다. 하지만 $\operatorname{Vim}$ 프로세스는 코드가 복잡하고 크기가 크며, 문서 작업 시 수정이 일어나는 부분을 알 수 없으므로 문서 데이터를 Heap 영역에 할당하여 사용하기 때문에 상대적으로 많은 메모리를 사용한다는 것을 알 수 있다.

Fig. 7의 In/Out Memory는 현재 프로세스의 Swap $\mathrm{In} / \mathrm{Out}$ 페이지에 대한 정보이다. 메모리 워크로드 수집기를 통하여 프로세스의 페이지 테이블에 접근하고, 가상 주소에 해당하는 페이지 테이블 엔트리의 페이지 상태 정보 필드가 유효한지에 대한 검사를 한다. 페이지 상태 정보 필드가 유 효하면 가상 주소에 해당하는 페이지는 실제 물리 메모리 공간 내에 위치하고 있다는 것을 의미한다. 하지만 페이지 테이블 엔트리 내에 값이 유효하지 않으면 할당된 페이지 자체가 메모리에 없다는 것을 의미하므로 Swap Out 페이지 의 구조체는 유효하지 않게 된다. 따라서, Swap Out 페이지 에 대한 페이지 구조체를 수집하지 않으며, 단순히 페이지 의 개수에 대한 정보만을 출력한다.

Fig. 8은 앞서 수집한 정보를 바탕으로 각 프로세스에 대 한 메모리 영역별 사용량과 Swap In/Out의 정보, 프로세스 의 전체 페이지에서 Swap In/Out에 대한 비율, 각 영역별 변경되는 페이지의 정보, 프로세스 전체 페이지에서 변경되 는 페이지에 대한 비율을 보여준다. Fig. 8(A)는 Tail 프로 세스의 워크로드 분석 결과를 보여준다. 수집된 결과를 분 


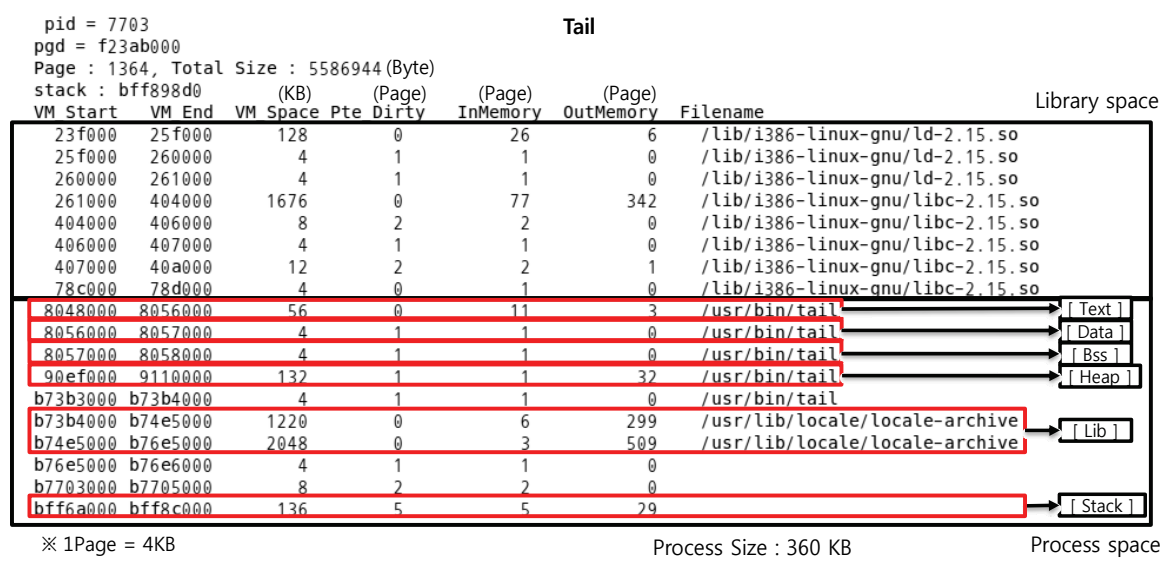

(A) Tail Process

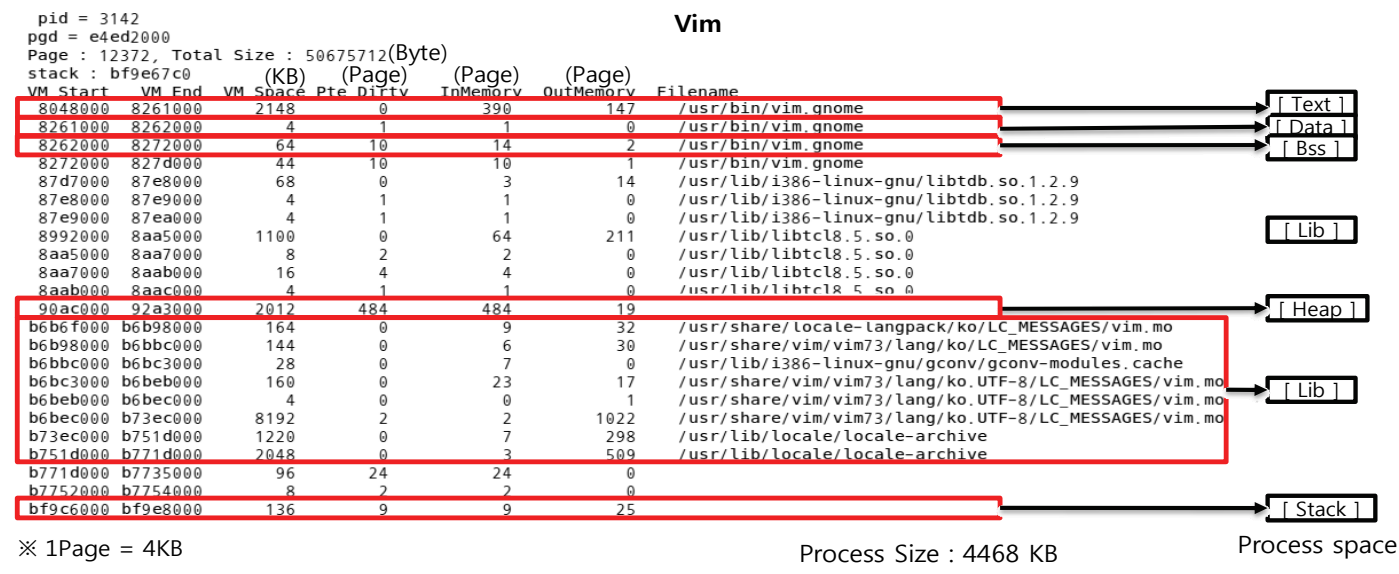

(B) Vim Process

Fig. 7. Data collection result of the each process for analysis
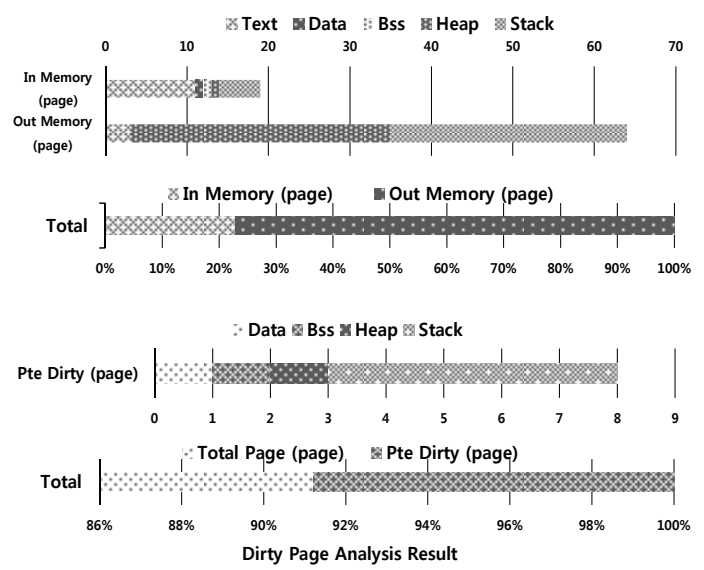

(A) Tail Process

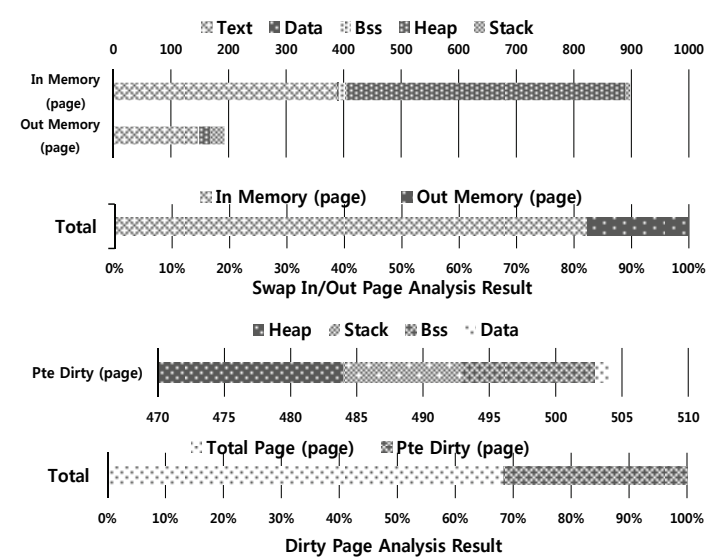

(B) Vim Process

Fig. 8. Memory workload analysis result of the each process

석하면 Tail 프로세스의 물리 메모리에 있는 페이지는 약 $23 \%$, 전체 변경되는 페이지는 약 $8 \%$ 로 메모리에 대한 워크 로드가 낮은 것을 알 수 있다. Fig. 8(B)는 Vim 프로세스의
워크로드 분석 결과를 보여준다. 수집 결과를 통해 물리 메 모리에 존재하는 페이지가 약 $83 \%$, 전체 페이지의 약 $32 \%$ 가 변경이 일어나는 페이지이므로 메모리에 대한 워크로드 
가 높다는 것을 알 수 있다.

본 실험에서 프로세스에 대한 데이터 수집의 범위와 수집 된 결과를 통해 메모리 워크로드 수집기에서 수집되는 데이 터의 일부를 확인할 수 있었으며, 실제 두 프로세스의 메모 리 워크로드 분석을 통해 비슷하거나 동일한 동작을 수행하 는 다른 프로그램 간의 메모리 워크로드에 대한 비교 등도 가능하다는 것을 알 수 있었다.

\section{5. 결 론}

본 논문에서는 메모리 워크로드 분석을 위한 고속 커널 데이터 수집 기법을 제안하였다. 기존의 메모리 분석기는 데이터를 수집하는데 있어 수집 속도가 느리거나 정형화된 정보로 인해 추가적인 작업이 필요하다는 단점을 가지고 있 었다. 하지만 제안하는 기법은 커널 데이터에 직접 접근하 여 사용자가 필요로 하는 데이터를 선택할 수 있으며, 프로 세스가 사용하는 물리 페이지를 직접 수집함으로써 메모리 워크로드 분석을 위한 데이터 수집의 속도를 기존 메모리 코어 덤프보다 약 80 배 이상 증가시켰다. 분석 결과에서 실 제 프로세스가 사용하는 메모리 영역에 대한 물리 페이지를 수집하여 실제 사용량을 분석하고 실행 프로세스에 대한 메 모리 워크로드를 보였다.

\section{참 고 문 헌}

[1] B. Ngueyn, "Proc File System," Specification, 2004, http://www.tldp.org/LDP/Linux-Filesystem-Hierarchy/html /proc.html/.

[2] M. Kerrisk, "Core Dump Manual," Specification, 2013, http://man7.org/linux/man-pages/man5/core.5.html/.

[3] Cat-v.org, "Process File System API," Specification, 2011, http://man.cat-v.org/unix_8th/4/proc/.

[4] Mission Critical Linux, "In Memory Core Dump," Specification, http://mclx.com/projects/mcore/.

[5] A. Cahalan, "Procps," Specification, 2009, http://procps. sourceforge.net/.

[6] I. Kollar. "Forensic RAM dump image analyser," Master's thesis, Department of Software Engineering, Charles University, Prague 2010.

[7] Raytheon Pikewerks, "Second-Look," Specification, http:// secondlookforensics.com/.

[8] draugr, "Live Memory Forensics on Linux," Specification, 2009, http://code.google.com/p/draugr/.

[9] Red Hat, "White Paper : Red Hat Crash Utility," White Paper, 2008, http://people.redhat.com/anderson/crash_whitepaper/.

[10] E. Girault, "Volatilitux," Specification, 2010, http://code. google.com/p/volatilitux/.

[11] Volatile Systems, "Volatility," Specification, 2013, https:// www.volatilesystems.com/default/volatility/.
[12] J. Sylve, "LiME-Forensics," Specification, 2012, http://code. google.com/p/lime-forensics/.

[13] M. Burdach, "Digital forensics of the physical memory," Specification, 2005, http://forensic.seccure.net/pdf/mburdach _digital_forensics_of_physical_memory.pdf/.

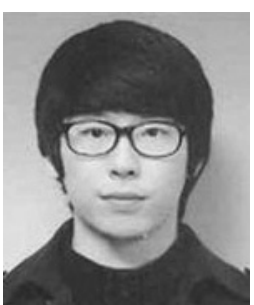

윤 준 영

e-mail :sdr12000@ee.knu.ac.kr 2013년 대구대학교 컴퓨터·IT공학부(학사) 2013년 현 재 경북대학교 전자공학부 석사과정 관심분야: 임베디드 시스템, 운영체제, 모바일 컴퓨팅

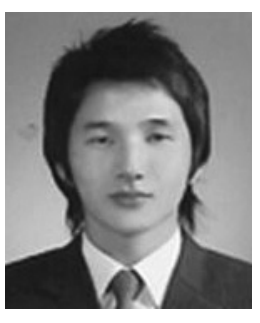

정 승 완

e-mail : tmdrod@ee.knu.ac.kr

2006년 경북대학교 전자전기컴퓨터학부 (학사)

2008년 경북대학교 전자전기컴퓨터학부 (석사)

2008년 현 재 경북대학교 전자전기 컴퓨터학부 박사과정

관심분야: 임베디드 시스템, 스토리지 운영기법, 무선 센서네트 워크

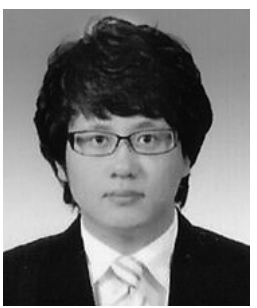

박 종 우

e-mail : jwpark0921@ee.knu.ac.kr 2011년 대구대학교 컴퓨터·IT공학부(학사) 2012년 현 재 경북대학교 전자공학부 석사과정 관심분야: 임베디드 시스템, 차세대 메모리

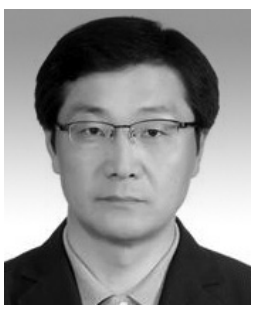

\section{김 정 준}

e-mail : jungkim7@ee.knu.ac.kr 1981년 경북대학교 전자공학과(학사) 1983년 한국과학기술원 전기 및 전자공학과 (석사)

1997년 Louisiana State Univ., 전기 및 컴퓨터공학과(박사)

1984년 2012년 (주) 케이티

2012년 현 재 경북대학교 전자공학부 교수

관심분야: 신호처리, 유무선통신, 컴퓨터 


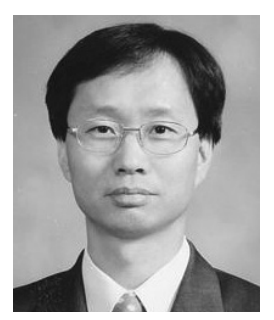

서 대 화

e-mail:dwseo@ee.knu.ac.kr

1981년 경북대학교 전자공학과(학사)

1983년 한국과학기술원 전산학과(석사)

1993년 한국과학기술원 전산학과(박사)

1983년 1995년 한국전자통신연구원

2004년 현 재 경북대학교 임베디드소프트 웨어연구센터장

1998년 현 재 경북대학교 전자공학부 교수

관심분야: 임베디드 $\mathrm{SW}$, 병렬처리, 분산운영체제 